\title{
Constitutional and legal status of a federal subject in the Republic of Iraq and in the Russian Federation: a comparative legal study
}

\author{
Waleed Taha Akram Toghramchy ${ }^{1}$ and Nahro Khasro Hussein \\ RUDN University, Law Institute, Department of Constitutional Law and Constitutional Proceedings, \\ Moscow, Russia
}

\begin{abstract}
The constitutional and legal status of subjects of various federations is the issue considered by many scientists, but the area of comparative legal research remains poorly studied. The article considers the basics and features of the constitutional and legal status of the subjects of two federations that are at the stage of formation as democratic and legal states: the Russian Federation and the Federal Republic of Iraq. The purpose of the comparative study is to identify common and different elements of the constitutional and legal status of the subjects of two states and to identify on their basis a model of the constitutional and legal status of a subject of a modern, democratic, and rule-of-law state. The work is based on the comparative-legal research method. The study reveals differences in the ways of achieving the goal of building a federal state in the Russian Federation and in the Republic of Iraq. It also determines the foundations and features of the constitutional and legal status of the subjects of the two federations. The analysis of the main constitutional and legal norms establishing the procedure for the division of powers between federal and regional state authorities is carried out. The study results allow concluding that it is necessary to amend the constitutional legislation of the Republic of Iraq in order to expand the constitutional and legal status of the subjects and improve federal relations within the country.
\end{abstract}

Keywords: constitution, federalism, federal subject, legal status, federal structure

\section{Introduction}

The federal structure of developing countries is currently undergoing a stage of its evolution, which has its own characteristics depending on the economic and political situation in the region. This study aims to analyze these differences using the example of two countries - the Federal Republic of Iraq and the Russian Federation.

Most developing countries that tend to implement the generally recognized principles of a democratic state and constitutional legal order on their territory do not always manage to ensure that public authorities comply with the rules, which are necessary to achieve legal heights.

\footnotetext{
${ }^{1}$ Corresponding author: waleedkani89@gmail.com
} 
The constitutional and legal status of the Republic of Iraq and the Russian Federation differ significantly from the status of subjects of the federation in developed states. The main difference is related to the constitutional and legal consolidation of this status, which does not correspond to the generally recognized norms and standards of a democratic and legal state.

The following researchers have discussed in their works the constitutional and legal status of subjects of the Russian Federation and subjects of the Federal Republic of Iraq: Dudko [1], Kazakova [2], Lebedev [3], Motalebi [4], Salwan [5], and others.

\section{Methods}

The purpose of the comparative study is to identify common and different elements of the constitutional and legal status of the subjects of two states and to identify on their basis a model of the constitutional and legal status of a subject of a modern, democratic, and rule-of-law state.

The study is based on the comparative-legal research method, as well as a complex of modern philosophical, general scientific, and special scientific methods of cognition.

\section{$3 \quad$ Results}

In order to conduct a comparative legal analysis of the constitutional and legal status of the subject in the Republic of Iraq and the Russian Federation, first of all, one must define the concept (notion) of a federal state. A federal state is a rather complex, composite state, the territory and population of which are simultaneously subject to the jurisdiction of state authorities at two levels - the federation and its constituent political-territorial entities (subjects of the federation), between which there is a strict, constitutionally guaranteed distinction of competencies [6].

A federal subject is one of constituent elements of the federal state. Regarding the concept of a subject of the Russian Federation, there is no special pluralism in the scientific doctrine due to the very high level of scrutiny of this question. For example, Lebedev gives a definition, pointing out the fact that a subject of the federation is a participant in federal relations: "a subject of the federation is a state (state-like) territorial entity within the federation that is a participant in federal legal relations" [7]. The Russian version of the federation consists only of subjects - there are no territories in the Russian Federation that are not subjects of the federation (for example, associated states, metropolitan areas, federal territories, and so on). Here it is worth making some refinements about the fact that intrastate entities (for example, closed administrative divisions, free economic zones, and so on) are not constituent subjects of the federation [8]. One of the most important norms in the topic under study is Article 65 of the Constitution of the Russian Federation, which, in addition to listing all eighty-five constituent entities of the Russian Federation, sets out in separate paragraphs also the types of subjects of the federation: republic ( 22 subjects), territory (9 subjects), region (46 subjects), federal city (3 subjects), autonomous district (1 subject) and an autonomous district (4 subjects).

According to Article 66 of the Constitution of the Russian Federation, the status of a Republic is determined by the Constitution of the Russian Federation and the Constitution of the Republic. The status of other entities is determined by the Constitution of the Russian Federation and the Charter of the subject, approved by the legislative body of this subject of the Russian Federation. Only with the mutual consent of the Russian Federation and its subject, the status of this subject can be changed. According to it, it is forbidden to raise the question of changing the status of a subject at an all-Russian referendum. The constitutions 
of the subjects of the Russian Federation, as well as the basic law of the Russian Federation, form the basis for the laws in these same subjects, which can be traced while referring to the Constitution of the Russian Federation. The rights and obligations of an individual subject are determined when considering its status [9].

In addition, these types of subjects of the Russian Federation can be grouped and the most general categories of them can be distinguished - types of subjects: subjects that are assigned to the corresponding type based on the national-state attribute (republic); administrative-territorial division (territories, regions, federal cities); national-territorial division (autonomous regions and districts). Not only the assignment but also any change in the name of the subjects of the federation is its prerogative and can be carried out only by the initiative of the subject of the federation itself. This position logically follows from the comparison of the content of Articles 71 and 72 of the Constitution of the Russian Federation. It is also confirmed by the Constitutional Court of the Russian Federation in its decision on the interpretation of part 2 of Article 137 of the Constitution of the Russian Federation No. 15-P of November 28, 1995 [10]. Finally, this provision can also be enshrined in the basic laws of the subjects of the Russian Federation themselves [11].

All constituent entities of the Russian Federation have similar equality. It should be changed only by mutual agreement of the Russian Federation and the subject of the Russian Federation. One of the most controversial issues is whether subjects have sovereignty. The position recognized in the doctrine does not allow for the idea that subjects have state sovereignty. For example, Baglay determines that the presence of sovereign republics within the federation is a serious contradiction to the very idea of federalism; therefore, the subjects of the federation do not have state sovereignty [12]. They have only elements of sovereignty, since they are somehow subordinated to the federal state authority, and their international relations are also controlled by the federal authorities.

Subjects have their own and sufficiently developed legal system.

Within the relevant boundaries, the subjects of the Russian Federation have their own territory, the borders of which can be changed only according to the mutual agreement of the subjects. Administrative divisions within the territory of subjects are set by them independently. Subjects also organize local self-governments within the given territory.

Modern science and constitutional law practice presuppose the division of state authority into separate branches at the level of not only the federal center but also in the constituent entities of the Russian Federation. Implementing the principle of separation of authority at the federal and regional levels of government functioning is possible based on the provisions of Article 10 of the Constitution of the Russian Federation. The Constitutional Court of the Russian Federation in a number of its decisions confirmed the possibility of extending this legal norm to the level of Russian regions (subjects). The most significant in this sense is the decision of the Constitutional Court of the Russian Federation of January 18, 1996 No. 2-P in the case of verification of the constitutionality of a number of provisions of the Charter (basic law) of the Altai Territory. In this decision, the court of the highest constitutional jurisdiction emphasized that the separation of powers was not only one of the foundations of the constitutional system as a whole but also extended its effect to the level of subjects of the Russian Federation, served as a reference point for the organization of state power in the regions [13].

The principle of separation of powers in the constituent entities of the Russian Federation creates the necessary constitutional and legal basis for organizing the system of regional power. The organization of power in subjects is based on general provisions of the Constitution of the Russian Federation, norms of the federal legislation, and specific provisions of constitutions and charters of constituent entities of the Russian Federation.

The above-mentioned features of the constituent entities of the Russian Federation are the most general categories that are inherent in all constituent parts of the Russian 
Federation. At the same time, analyzing the status of certain types of subjects of the Russian Federation, one can conclude that there are significant differences in the scope of their rights and obligations. Republics have the largest amount of authority, and autonomous districts and regions have the smallest, since they are often included in other subjects of the Russian Federation; this means that they partially depend on the decisions of the state bodies of these subjects. At the same time, it cannot be denied that the constitutional and legal status of all subjects of the Russian Federation is quite democratic, and they also have a great potential to take further steps towards achieving even greater democracy in the construction of state power and the federation as a whole [14].

First of all, for further research of the constitutional and legal status of the constituent entities of the federation in the Republic of Iraq, it is necessary to formulate the features of modern state-building in the Republic of Iraq.

Since 2003, the political system of Iraq has been constantly hit by political crises. For a long time, the state could not develop an effective strategy to get the country out of a difficult situation. The process of building an Iraq state is characterized by reliance on the principles of interfaith and ethnic relations, which are factors that hinder the return of Iraq's independence [15].

The composition of the Government of the Republic of Iraq was formed from representatives of the two main religious doctrines, which was due to a large number of conflicts between governments of subjects when making a particular decision or regulatory legal act.

At the moment, one can identify a number of serious problems that are difficult to overcome and obstacles to building a democratic state governed by the rule of law in Iraq and the development of the subjects of the Russian Federation:

Corruption. From 2003 to 2020, Iraq was at the bottom of the list. According to the index of corruption perception, it is considered one of the most corrupt countries in the world. It is also worth noting that the Republic of Iraq will remain at the bottom of the corruption perception index for a longer period than expected by the Iraqi and international community. This is due to a decline in development opportunities, investment, and the undermining of the legitimacy of the achievements of the existing political system. In the era of previous regimes, until September 4, 2003, political corruption reached such a scale and distribution that the interconnectedness of its mechanisms has begun to threaten the stability of the political system. At the moment, there are obstacles to building political institutions and the process of developing self-reliance subjects of the Russian Federation [16].

Religious intolerance. This problem refers to the intolerance of representatives of one religious movement to another, namely, the incessant confrontation and hostility between Sunnis and Shiites, which extends to the political arena, as well as to the sphere of relations between subjects with the federal center, as well as subjects among themselves.

The crisis of trust is the loss of political trust in the entire political process in the two countries' parties. Iraq, as known, is divided into several religious and ethnic groups, between which there has long been a lack of social harmony. The main problem that threatens territorial integrity is the goal of the Iraqi state to create an ethno-confessional group of Kurds inhabiting one of the constituent entities of the Russian Federation (Iraqi Kurdistan), to gain independence and secede from the Kurdistan region of the Federal Republic of Iraq [16].

External interference. The problem of external interference in Iraq is considered a serious difficulty in achieving internal political harmony between political trends and the subjects of the federation, since the interaction and the scale of changes have pushed neighboring countries to actively participate in Iraqi politics and benefit from the problems of post-change. 
Political culture. The low level of the political culture of the Iraqi people is also a real challenge. The lack of this culture is an obstacle to progress in state construction.

Low efficiency of the public administration. In Iraq, there is a great need for qualified personnel to perform functions related to public administration, both at the federal and regional levels. The constant threat to state security has led to inefficiency in the performance of other tasks of state authorities. The incompetence of state and municipal employees led to the formation of a system of state and municipal employees in Iraq public authorities that are unable to manage the state apparatus [17].

Low quality of the Basic Law of the Federal Republic of Iraq. The Constitution is the fundamental and most important normative legal act for most modern democratic legal states. As a rule, the drafting of this document takes a lot of time, since the preparation of standards of this level is a very responsible and difficult process.

Democratization, which has covered most of the world's countries since the middle of the last century, has made it necessary for states to reform their state-legal systems, which, among other things, were aimed at the constitutional and legal status of subjects of the Russian Federation. Part of these reforms was the ratification of the most important international documents in the field of human rights, followed by the implementation of relevant international norms in national legislation and their further implementation.

The controversial position of the developers of the idea that the central government has less power than regional governments has created a chronic problem for the state. Attempts to establish a federal law, the rush to draft a Constitution, numerous foreign interventions, a real lack of constitutional experts in Iraq, a weak central government, and sharp divisions have all contributed to the volatile situation in Iraq. Consensus must be reached through constructive dialogue between the various blocs that dominate the Parliament. It is worth investigating in more detail the features of the constitutional construction of the Republic of Iraq, which directly influenced the formation of a certain constitutional and legal status of the constituent entities of the Russian Federation and the subjects of the Republic of Iraq [18].

It should be noted that human rights were gradually established in the constitutions of Arab States so that the Islamic conservative society could comprehend the new freedoms. Another important reason for the slow implementation of human rights norms in the Constitution of Arab States is that human rights were poorly combined with religious and traditional Islamic law, in which religion and faith in God played a decisive role, and its dogmas gave rise to various obligations to God, the state, and society.

\section{Conclusion}

In the current conditions of development of the constitutional and democratic foundations of the state structure, it is important to take into account certain features of each of the studied states, which were studied in detail through the example of the Russian Federation and the Republic of Iraq.

In the comparative analysis of the constitutional and legal statuses of subjects of the Republic of Iraq and the Russian Federation, it is also worth noting that these research subjects have common goals, but the result at the moment is absolutely the opposite. For example, the subjects of the Russian Federation at the moment in practice have a limited number of powers; therefore, they can independently carry out their own activities without the control of their actions by the federal government.

When summarizing all of the above, it is worth formulating the following conclusion. Such trends and phenomena as the full legal elimination of republican citizenship, the blurred question of the exclusive authority of the constituent entity of the Russian Federation, the weakening of state protection of the national languages of the republics, are 
the negative factors from the perspective of federalism. The continuation of such a policy may lead to a unitary form of government with all the ensuing state structure effects.

The opposite situation arises with the constitutional and legal status of the subjects of the Federation of the Republic of Iraq. General ideas aimed at the development of the constitutional and legal system were formulated, but in practice, the subjects of the Federation of the Republic of Iraq are not that independent in their actions within the Republic of Iraq, but rather fragmented and have a large number of internal conflicts at the moment. It is important to understand that when building the generally recognized principles of the constitutional and legal system of the state, the subjects of the federation are more independent in their powers, but also form the overall integrity of the entire state without aggravating conflicts within the state. It is necessary to further develop the constitutional and legal status of the subjects of the federation under study, since they are at an active stage of forming basic constitutional and legal provisions in the conditions of modern instability. The basis of any state is its independent and independent regions, which is important to take into account when developing future regulations, taking into account checks and balances.

Thus, it is worth noting that in the situation of the post-war period and the existing national and religious contradictions in the Republic of Iraq, the development of the federation on the basis of asymmetry is a method of balancing the centrifugal tendencies in the federal constitutional and legal construction of the subjects of the federation. The formation of the stability of the state structure in the Republic of Iraq implies the equalization of the status of certain subjects.

For this key purpose, further amendments to the constitution and legal acts of the Republic of Iraq are necessary:

1) direct naming in Article 106 of the Constitution of all territorial units in the state as subjects of the federation;

2) the definition of all subjects of the federation in a specific article of the Constitution in alphabetical order, for which it is necessary to supplement the Constitution with a new Article 111.1;

3) determination of the requirement for the existence of a Constitution (basic law) in any of the subjects, regardless of its variety.

The proposed changes, in the authors' opinion, should have a positive impact on the constitutional and legal status of the subjects of the Republic of Iraq, which will lead to an improvement in federal relations.

\section{References}

1. I.G. Dudko, Constitutional and Municipal Law, 8, 1-10 (2011)

2. E.V. Kazakova, Bulletin of the Russian University co-ops, 2(8), 70-73 (2012)

3. V.A. Lebedev, Bulletin of the Chelyabinsk State University, 1, 5-12 (2012)

4. M. Motalebi, A Study of Federalism in Iraq from the View of the Micro Level of Analysis, $1^{\text {st }}$ ed., 493-498 (The Foreign Ministry's Center of Print and Publication, Tehran, 2015)

5. J.H. Salwan, (2017) Agreement on military-technical cooperation between the government of the Russian Federation and the government of the Republic of Iraq: content and implementation, 1042-1049 (Kazan Federal University, 2017)

6. M.N. Fedorets, State and Law, 4, 100 (2015)

7. V.A. Lebedev, Bul. Chelyabinsk State Univ. 1, 7 (2012)

8. V.I. Birladeanu, Federalism, 2(62), 81-88 (2011) 
9. S.V. Semin, Sci. Society. State 1(1), 227-232 (2013)

10. Postanovlenie Konstitutsionnogo Suda RF ot 28 noyabrya 1995 g. N 15-P "Po delu o tolkovanii chasti 2 stati 137 Konstitutsii Rossiiskoi Federatsii" [Resolution of the Constitutional Court of the Russian Federation of 28.11.1995 N 15-P "In the case of the interpretation of part 2 of Article 137 of the Constitution of the Russian Federation"]. Accessed on: August 07, 2021. [Online]. Available: http:http://www.constitution.ru/decisions/10005627/10005627.htm

11. A.S. Morozova, Manag. Iss. 1(18) (2012)

12. M.V. Baglay, Yu.I. Leybo, L.M. Antin (eds.), Konstitutsionnoe pravo zarubezhnykh stran [Constitutional law of foreign countries] (Yur. Norma, NITs INFRA-M, Moscow, 2016)

13. M.V. Demidov, Const. and Munic. Law 1, 33 (2017)

14. S.M. Gorokhovatsky, Const. and Munic. Law 1, 4 (2016)

15. P. Billon, Middle East Policy, 22(1) (2015)

16. A. Alishahi, Z. Hossein Pour, S.H. Souchelmaei, J. Cult. Soc. Anth. 1(3), 31 (2019)

17. T. Davis, Int. J. Cult. Property 21(4), 446 (2014)

18. E.M. Alsamee, H.A. Wahab, Y. Yusof, World J. Res. Rev. 3(2), 1-4 (2016) 